\title{
Association between Blood Group and Hepatitis B Virus Infection in Blood Donors in West Bengal
}

\author{
Arpita Halder ${ }^{1}$, Arup Kumar Halder ${ }^{2}$ \\ ${ }^{1}$ Department of Anatomy, College of Medicine and Sagore Dutta Hospital, Kamarhati, Kolkata, India. \\ ${ }^{2}$ Department of Pulmonology, Woodlands Multispciality Hospital, Kolkata, India.
}

\section{ABSTRACT}

\section{BACKGROUND}

Blood donated by blood donors is collected in blood bags and the blood is screened for transfusion transmitted infections like Hepatitis B Virus (HBV), Hepatitis C Virus (HCV), Human Immunodeficiency Virus (HIV), and Syphilis in Blood Banks. Institution of Blood Transfusion Medicine (IBTMI) is a blood bank in Kolkata, West Bengal, collecting blood from a large area of Kolkata, and adjacent districts of West Bengal. The relation between HBV seropositivity, ABO blood group and Rh type is evaluated in this study.

\section{METHODS}

Records of blood collected by Institute of Blood Transfusion Medicine and Immunohaematology (IBTMI), Kolkata, West Bengal are studied. The data collected are used as secondary data. More than 2 lakh blood donors were recorded during this study. The collected blood undergoes testing for the Transfusion Transmitted Infections (TTI). All the blood bags that are collected are ABO grouped and Rh typed.

\section{RESULTS}

In three consecutive years of study, it is found that seropositivity of HBV infection is highest amongst blood donors having blood group $\mathrm{AB}$ Negative. $3.2 \%$ of blood donors having AB Negative (AB-ve) blood group were found positive for Hepatitis $B$ Virus (HBV) infection in the year 2007. 3.96\% and $2.42 \%$ of blood donors with blood group AB-ve were found for positive for HBV infection in 2008 and 2009 respectively. While percentage was calculated with $\mathrm{ABO}$ group and Rh types taken separately, results were found to be different. Statistical analysis was done to compare the findings.

\section{CONCLUSIONS}

Following statistical analysis, we can conclude that the Hepatitis B Viral infections may have an association with a particular blood group and Rh type.

\section{KEY WORDS}

Blood Donor, ABO Blood Group and Rh Type, Transfusion Transmitted Infections (TTI), Hepatitis B Virus (HBV).

\author{
Corresponding Author: \\ Dr. Arpita Halder, \\ 1/1F, Satin Sen Sarani \\ (Maniktala Main Road), Kolkata - 700054, \\ E-mail: drarpitachat@ymail.com
}

DOI: $10.14260 /$ jemds/2020/818

How to Cite This Article:

Halder A, Halder A. K, et al. Association between blood group and hepatitis $b$ virus infection in blood donors in West Bengal. J Evolution Med Dent Sci 2020;9(49):37263730, DOI: 10.14260/jemds/2020/818

Submission 26-08-2020,

Peer Review 19-10-2020,

Acceptance 26-10-2020,

Published 07-12-2020.

Copyright (C) 2020 Halder A. et al. This is an open access article distributed under Creative Commons Attribution License [Attribution 4.0 International (CC BY 4.0)] 


\section{BACKGROUND}

Blood donors donate blood to help patients recover from diseases that require blood transfusion. Blood transfusion can save lives. Blood donors from around the world donate blood for helping patients who suffer from acute or chronic blood loss, due to injury or surgical procedures and diseases like thalassemia, sickle cell anaemia, malignancy. During blood transfusion the health care personnel should match the blood group of the donor and recipient. It is the blood bank where blood is ABO grouped and Rh typed and is screened for any transfusion transmitted infections. Otherwise, this infection can spread from a donor to a recipient. WHO recommends compulsory screening of all blood donors for HBV, HCV, HIV and Syphilis ${ }^{1}$ The bags in which blood is collected from donors are stored in a blood bank. The blood bag undergoes ABO grouping and $\mathrm{Rh}$ typing and are screened for transfusion transmitted infections like Hepatitis B Virus (HBV), Hepatitis C Virus (HCV), Human Immunodeficiency Virus (HIV) at the blood banks.

It is noticeable in the Global Hepatitis B report in 2017, 257 million people are having this infection.2,3 The ABO blood group system is an erythrocyte antigen system and influences the host susceptibility to various diseases. These blood antigens are important receptors for immune and inflammatory process. ${ }^{4}$ Earlier, studies have revealed a relationship between blood groups and Hepatitis B, but with inconsistency. A particular blood group may be more susceptible to an infective agent whereas the same blood group may be less infected by some other disease-causing organism. Lao et al, found higher prevalence of of this infection in blood group $0(10.2 \%), 5$ but other authors ${ }^{6}$ found that Hepatitis B surface antigens were lower in blood group 0 . Szmuness et al ${ }^{7,8}$ and Behal et al ${ }^{9}$ failed to find any relationship with Hepatitis B and blood groups. In a retrospective study carried out by Sreedharbabu KV et al in Department of Transfusion Medicine at a tertiary teaching hospital blood bank, for 6 years found no association between Transfusion Transmitted infection seroprevalence and blood group. ${ }^{10}$ Tyagi et al found $\mathrm{Rh}$ negative blood group is more prone to transfusion transmitted infections. ${ }^{11}$ Omar et al reported that HBsAg and Anti HCV antibody is found to be higher in donors with blood group $\mathrm{O}$ and lowest in donors with $\mathrm{AB}$ blood group. Distribution of $\mathrm{Rh}$ type in Hepatitis infection was higher amongst $\mathrm{Rh}+\mathrm{ve}$ donors. ${ }^{12}$ According to Das et al, the frequency of HBsAg and Anti HCV antibody among blood donors had maximum association with blood group $0+v e .{ }^{13}$ Kumar et al found highest prevalence of transfusion transmitted viral infections is seen in individuals with blood group 0 and Rh+ve. ${ }^{14}$ The present study determines the seroprevalence of Hepatitis B Virus and its relationship to different blood groups amongst blood donors recorded at this institution.

Aim of the study: The study intends to detect first the number of blood donors of each blood group and the number of blood donors of each group testing positive for HBV infection. Then to find out the percentage of donors of each $\mathrm{ABO}$ group and $\mathrm{Rh}$ type testing positive for HBV and then to evaluate any predilection of a blood group for Hepatitis B Viral infection.

\section{METHODS}

The study was conducted at Institute of Blood transfusion Medicine and Immunohaematology (IBTMI), Kolkata in association with Department of Anatomy and Department of Community Medicine, R G Kar Medical College, Kolkata. The study period was from 1st January 2007 to $10^{\text {th }}$ October 2009. The design of the study is Institutional Record Based retrospective study. All blood donors donating blood to this institute and the blood camps organised by this Institute are recorded. All the registered donors were included for the study for whom the complete records were available. There was no inclusion or exclusion criteria. This is a census type of secondary data. Blood bags collected from each donor were ABO blood grouped and Rh typed. Microwell ELISA test is used for qualitative detection of Hepatitis B surface antigen (HBsAg) in plasma.

\section{Statistical Analysis}

Descriptive statistical analysis has been carried out in the present study. Significance is assessed at the level of $5 \%$. A 'p value' of $<0.05$ was considered as statistically significant. The software used for calculation of significance between two proportions is MedCalc, Version 19.5. It uses 'N1' Chi-squared test as recommended by Campbell (2007) and Richardson (2011). Other software used in the study were PSPP, Version 3 (2007), Microsoft word (2007) and Microsoft Excel (2007).

\section{RESULTS}

The total number of blood donors were 2,97,725 in three years of study. The complete records were available for this population and they were analysed. In 2007, HBV was more prevalent in AB blood group (2.64\%), followed by B (2.22 \%). (Table 1) The value of $\mathrm{z}$ is -2.496 and $\mathrm{p}$ value is 0.01242 when compared between these two groups. That suggests HBV was statistically more prevalent in group $\mathrm{AB}$ in 2007. But individual analysis of $\mathrm{ABO}$ with $\mathrm{Rh}$ showed the prevalence was most common in AB-ve (3.2\%), followed by $A B+v e(2.62 \%$.). The value of $\mathrm{z}$ was -0.6353 and $\mathrm{p}$ value was 0.52218 . It suggests that the difference in prevalence between the two groups was not statistically significant.

\begin{tabular}{|cccc|}
\hline $\begin{array}{c}\text { Blood } \\
\text { Group }\end{array}$ & $\begin{array}{c}\text { Total No. of } \\
\text { Donors }\end{array}$ & $\begin{array}{c}\text { HBV Positive } \\
\text { Donors }\end{array}$ & Percentage \\
A+ve & 23281 & 429 & $1.84 \%$ \\
A-ve & 791 & 17 & 2.14 \\
Total & $\mathbf{2 4 0 7 2}$ & $\mathbf{4 4 6}$ & $\mathbf{1 . 8 5}$ \\
B+ve & 37836 & 844 & 2.23 \\
B-ve & 1199 & 23 & 1.91 \\
Total & $\mathbf{3 9 0 3 5}$ & $\mathbf{8 6 7}$ & $\mathbf{2 . 2 2}$ \\
O+ve & 32641 & 518 & 1.58 \\
O-ve & 1030 & 13 & 1.26 \\
Total & $\mathbf{3 3 6 7 1}$ & $\mathbf{5 3 1}$ & $\mathbf{1 . 5 7 7}$ \\
AB+ve & 9362 & 246 & 2.62 \\
AB-ve & 311 & 10 & 3.2 \\
Total & $\mathbf{9 6 7 3}$ & $\mathbf{2 5 6}$ & $\mathbf{2 . 6 4}$ \\
\hline \multicolumn{4}{c}{ Table 1. Seroprevalence of HBV According to } \\
Blood Group and Rh Type (Year 2007) \\
\hline Total Number of Donors = 106451) \\
\hline \multicolumn{4}{c}{} \\
\hline
\end{tabular}




\begin{tabular}{|c|c|c|c|}
\hline $\begin{array}{l}\text { No. of Blood } \\
\text { Donors }\end{array}$ & & $\begin{array}{l}\text { No. of HBV } \\
\text { Positive }\end{array}$ & $\begin{array}{l}\text { Percentage } \\
\text { of } \mathrm{HBV}+\mathrm{ve}\end{array}$ \\
\hline Rh Positive 103120 & & 2037 & 1.975 \\
\hline Rh Negative 3331 & & 63 & 1.89 \\
\hline \multicolumn{4}{|c|}{ Table 2. Sero Prevalence of HBV According to Rh Type (2007) } \\
\hline $\begin{array}{l}\text { Blood } \\
\text { Group }\end{array}$ & $\begin{array}{l}\text { Total No. } \\
\text { of Donors }\end{array}$ & $\begin{array}{l}\text { HBV Positive } \\
\text { Donors }\end{array}$ & Percentage \\
\hline$A+v e$ & 24997 & 512 & 2.04 \\
\hline A-ve & 831 & 20 & 2.4 \\
\hline Total & 25828 & 532 & 2.5097 \\
\hline$B+v e$ & 40624 & 899 & 2.21 \\
\hline B-ve & 1206 & 35 & 2.9 \\
\hline Total & 41830 & 934 & 2.23 \\
\hline $0+v e$ & 35167 & 642 & 1.82 \\
\hline O-ve & 988 & 23 & 2.32 \\
\hline Total & 36155 & 665 & 1.8393 \\
\hline$A B+v e$ & 10072 & 236 & 2.34 \\
\hline AB-ve & 328 & 13 & 3.96 \\
\hline Total & 10400 & 249 & 2.3942 \\
\hline \multicolumn{4}{|c|}{$\begin{array}{l}\text { Table 3. Seroprevalence of HBV According to } \\
\text { Blood Group and Rh Type (Year 2008) }\end{array}$} \\
\hline \multicolumn{4}{|c|}{$($ Total Number of Donors $=114213)$} \\
\hline
\end{tabular}

\begin{tabular}{|c|c|c|c|}
\hline No. of Blood Donors & \multicolumn{2}{|c|}{ No. of $\mathrm{HBV}+\mathrm{ve}$} & tage of $\mathrm{HBV}+\mathrm{ve}$ \\
\hline Rh Positive 110860 & \multirow{2}{*}{\multicolumn{2}{|c|}{$\begin{array}{c}2289 \\
91\end{array}$}} & 2.0647 \\
\hline Rh Negative 3353 & & & 2.7139 \\
\hline \multicolumn{4}{|c|}{ Table 4. Seroprevalence of HBV According to Rh Type (2008) } \\
\hline $\begin{array}{l}\text { Blood } \\
\text { Group }\end{array}$ & $\begin{array}{l}\text { Total No. } \\
\text { of Donors }\end{array}$ & $\begin{array}{l}\text { HBV Positive } \\
\text { Donors }\end{array}$ & Percentage \\
\hline A+ve & 16934 & 256 & 1.51 \\
\hline A-ve & 573 & 06 & 1.04 \\
\hline Total & 17507 & 262 & 1.4965 \\
\hline $\mathrm{B}+\mathrm{ve}$ & 27429 & 462 & 1.68 \\
\hline B-ve & 850 & 15 & 1.76 \\
\hline Total & 28279 & 477 & 1.6867 \\
\hline $0+v e$ & 23568 & 353 & 1.49 \\
\hline O-ve & 645 & 12 & 1.86 \\
\hline Total & 24213 & 365 & 1.5074 \\
\hline$A B+v e$ & 6856 & 107 & 1.56 \\
\hline AB-ve & 206 & 05 & 2.42 \\
\hline Total & 7062 & 112 & 1.5859 \\
\hline \multicolumn{4}{|c|}{$\begin{array}{l}\text { Table 5. Seroprevalence of HBV According to } \\
\text { Blood Group and Rh Type (Year 2009) }\end{array}$} \\
\hline l Number of Dono & ors $=77061$ ) & & \\
\hline
\end{tabular}

\begin{tabular}{|ccc|}
\hline No. of Blood Donors & No. of HBV +ve & Percentage of HBV +ve \\
Rh Positive 77787 & 1178 & $1.5143 \%$ \\
Rh Negative 2274 & 38 & $1.6710 \%$ \\
\hline Table 6. Sero Prevalence of HBV According to Rh Type (2009) \\
\hline
\end{tabular}

\begin{tabular}{|c|c|c|c|c|c|}
\hline 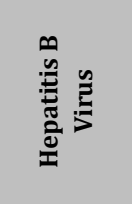 & 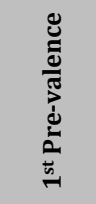 & 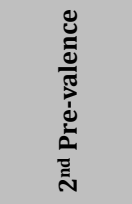 & 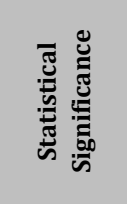 & 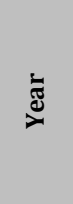 & 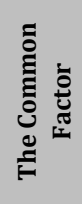 \\
\hline $\begin{array}{l}\text { Individual } \\
\text { blood group }\end{array}$ & $\begin{array}{c}\mathrm{AB} \\
\text { negative }\end{array}$ & AB positive & $\begin{array}{c}\text { No } \\
\mathrm{p}=0.52218\end{array}$ & 2007 & $\mathrm{AB}$ \\
\hline $\mathrm{ABO}$ & $\mathrm{AB}$ & B & $\begin{array}{c}\text { Yes } \\
\mathrm{p}= \\
0.01242\end{array}$ & 2007 & \\
\hline $\mathrm{Rh}$ & +ve & -ve & $\begin{array}{c}\text { No } \\
\mathrm{p}=0.72786\end{array}$ & 2007 & \\
\hline $\begin{array}{c}\text { Individual } \\
\text { blood group }\end{array}$ & $\begin{array}{c}\mathrm{AB} \\
\text { negative }\end{array}$ & $B$ negative & $\begin{array}{c}\text { No } \\
\mathrm{p}=0.32708\end{array}$ & 2008 & \\
\hline ABO & A & $A B$ & $\begin{array}{c}\text { Yes } \\
\mathrm{p}=0.0477\end{array}$ & 2008 & \\
\hline $\mathrm{Rh}$ & -ve & $+v e$ & $\begin{array}{c}\text { Yes } \\
\mathrm{p}=0.0096\end{array}$ & 2008 & -ve \\
\hline $\begin{array}{l}\text { Individual } \\
\text { blood group }\end{array}$ & $\begin{array}{c}\mathrm{AB} \\
\text { negative }\end{array}$ & 0 negative & $\begin{array}{c}\text { No } \\
\mathrm{p}=0.61006\end{array}$ & 2009 & $? \mathrm{AB}$ \\
\hline $\mathrm{ABO}$ & B & $\mathrm{AB}$ & $\begin{array}{c}\text { No } \\
\mathrm{p}=0.5552\end{array}$ & 2009 & \\
\hline $\mathrm{Rh}$ & -ve & +ve & $\begin{array}{c}\text { No } \\
\mathrm{p}=0.5485\end{array}$ & 2009 & \\
\hline
\end{tabular}

When analysis was carried out with respect to only $\mathrm{Rh}$ positive or negative status it was found that, the HBV was more prevalent in Rh+ve (1.975 \%), compared to Rh-ve (1.89\%). The significance of two proportions in two groups as: the value of $\mathrm{z}$ is 0.3433 , with $\mathrm{p}$ is 0.72786 . The result is not significant at $p<0.05$. That suggests that the difference in proportions between two groups (Rh positive and Rh-negative blood donors) is not statistically significant. (Table 2).

In 2008, HBV was more prevalent in blood group A (2.5097), followed by AB (2.3942) (Table 3). The $\mathrm{z}$ value is 1.9829 and $p$ value is 0.0477 , when compared between these two groups. The result is significant at $\mathrm{p}<0.05$. So, group A had statistically significant higher prevalence in 2008. But individual analysis of $\mathrm{ABO}$ and $\mathrm{Rh}$ showed the prevalence was most common in AB-ve (3.96 \%), followed by B-ve (2.9\%.). The value of $\mathrm{z}$ was -0.9788 and $\mathrm{p}$ value was 0.32708 . It suggests that the difference in prevalence between the two groups was not statistically significant.

The HBV was more prevalent in Rh-ve (2.7139\%), compared to $\mathrm{Rh}+\mathrm{ve}(2.0647 \%)$. The value of $\mathrm{z}$ is -2.5929 . The value of $p$ is 0.0096 . That suggests HBV prevalence was statistically significant in Rh-ve in 2008. (Table 4)

The prevalence of HBV was highest in blood group B (1.6867\%), followed by AB (1.5859\%) in 2009. (Table 5) The $\mathrm{z}$ value was 0.592 and $\mathrm{p}$ value was 0.5552 , when compared between these two groups. So, the difference of prevalence of HBV between B and AB is not statistically significant in 2009 . But individual analysis of $\mathrm{ABO}$ and $\mathrm{Rh}$ showed the prevalence was most common in AB-ve (2.42\%), followed by O-ve (1.86 $\%$.). The value of $z$ was -0.5061 and $p$ value was 0.61006 . It suggests that the difference in prevalence between the two groups was not statistically significant.

The prevalence of HBV was more in Rh-ve (1.6710\%), compared to $\mathrm{Rh}+\mathrm{ve}(1.5143 \%)$. The value of $\mathrm{z}$ is -0.6021 and $p$ value was 0.5485 . That suggests the difference of prevalence between two groups is not statistically significant. (Table 6). A comparative analysis of the results of three consecutive years is shown in Table 7 .

\section{DISCUSSION}

The present study is not an exception to the worldwide researches going on to find out relationship between $\mathrm{ABO}$ blood group and Rh type and various infective agents affecting the human race. The present study is quite different from other studies. A huge population is involved in the study. As the number of donors ABO Grouped and Rh typed and tested for HBsAg are high, the relationship thus revealed is determined to be the strength of this study.

$\mathrm{AB}$ negative blood group was the commonest blood group associated with Hepatitis B infection for 3 consecutive years, as revealed in the present study. A subgroup analysis was performed to see the statistical correlation of $\mathrm{ABO}$ with Hepatitis B infection for each year. Apart from individual blood group, an analysis was done separately for $\mathrm{ABO}$ and $\mathrm{Rh}$. This was done to corroborate or reconfirm the primary finding of this study, which is the association of $A B$ negative blood group and increased chance of Hepatitis B infection. The subgroup analysis definitely revealed more chances of infection with Hepatitis B with AB blood group and Rh-negative status. The only weakness of the study is that it was done in a specialised population of blood donors, which may not be reflective of 
general population, as this infection may be transmitted more frequently in blood donors.

Abdullah et al made a retrospective analysis of all blood bank records at Aseer Central Hospital, covering a total of 5174 blood donors during the period of one year starting from April, 2000. He found amongst 4664 Saudis and 510 nonSaudis screened, $17.9 \%$ of Saudis and $34 \%$ of Non-Saudis were HBV infected. ${ }^{15}$ Prabhakar K commented that at Apollo Hospital, Madras, they have been screening blood donors for HIV since 1988 along with HBsAg. HBsAg positivity rate was found to be 10.2 per 1000 donor. He also mentioned that high prevalence of HBsAg gets overshadowed by the current concern for AIDS.16 A G Kulkarni et al studied 1860 serum samples of blood donors from northern Nigeria, who were tested for HBsAg, $8.9 \%$ were tested positive. Significant differences in frequency were observed amongst various ethnic groups as well as ABO blood groups. ${ }^{17}$

Joshi et al found in his study population, 0 positive was most common followed by $\mathrm{A}+\mathrm{ve}, \mathrm{B}+\mathrm{ve}, \mathrm{AB}+\mathrm{ve}$ respectively. The analysis of relationship showed a tendency of high affinity of those diseases (HIV and HBV) in the subjects with $\mathrm{O}+\mathrm{ve}$ blood group. However, no real relationship of those infection was found with the blood groups. ${ }^{18} \mathrm{C}$ Odenigbo et al working at Nnamdi Azikwee Teaching Hospital from 2005 to 2009, tested 1229 blood donors (in Nnewi, South Eastern Nigeria) and found maximum seroprevalence of HCV in blood donors with blood group $0+v e .^{19}$

M S Anwar et al, in department of pathology, Nawaz Sarif social security hospital, Lahore screened 16695 blood donors for Hepatitis B and Hepatitis C viral infection. HCV infection was most prevalent in blood group 0 positive (8.96\%). The study was carried out from January to December. ${ }^{20}$

A retrospective study done by KV Sreedharbabu et al studied 41652 blood donors for 6 years, from January 2009 to December 2014. The commonest blood group that he found was 0 positive. Amongst total HBV positive donors $41.7 \%$ were 0 Positive. This was followed by B (30.9\%), A (21.6 \%) and $\mathrm{AB}(5.7 \%)$. He concluded there is no association between blood group antigen and these infections. ${ }^{10}$ Omar AAA et al reported similar results ${ }^{12}$ stating 0 blood group having higher seroprevalence of Hepatitis infections. Masoud Sabouri Ghannad et al, in a study conducted in Hamadan, Iran, amongst a number of 228409 people donating blood, found that A-ve, $\mathrm{B}+\mathrm{ve}$ and $\mathrm{A}+\mathrm{ve}$ were the most prevalent blood groups infected with HBsAg respectively. ${ }^{21}$ Mohammadali F et al studied blood donors in Tehran Blood Transfusion Centre from the year 2005 to 2011. 2031451 blood donors were studied. They found a significant association between blood group and Hepatitis B and HIV infection. According to them donors with blood group A had higher percentage of HIV whereas donors with blood group 0 had lower percentage of Hepatitis B. ${ }^{6}$ Nigam J S et al studied 4128 blood donors from January 2010 to April 2014.

They found highest percentage of HBsAg in blood group Ave, followed by A+ve.22 Liu et al found in Chinese adult population of 3827125 participants, prevalence of HBsAg to be $5.34 \%$ in blood group 0, $5.55 \%$ in A, $5.18 \%$ in B and $5.06 \%$ in AB. HBs Ag prevalence was $5.65 \%$ in Rh D +ve and $3.96 \%$ in Rh D-ve participants. ${ }^{23}$ Memon F A et al found in their study, a high frequency of HBsAg, VDRL and malaria positivity among O-ve donors. Donors with B -ve blood group were commonly infected with HCV as compared to other blood groups. HIV was most common in A+ve ${ }^{24}$ Arif SH et al studied 36614 donors. Overall seroreactivity for TTI was $5.59 \%$. Maximum seroreactive donors were positive for HBsAg. Highest seroreactivity was found in B +ve. Statistical analysis showed significant association between $\mathrm{Rh}+\mathrm{ve}$ group and HBsAg seropositive donor. ${ }^{25}$

Here we have discussed about how researchers have established relationship between blood group and Rh type and transfusion transmitted infections. Thus, we find, although many of these previous studies had found blood group 0 having commonest association with Hepatitis B, but the present study revealed a different blood group (AB Negative) to be associated with Hepatitis B. Other studies mentioned above also found few other blood groups as commonest association with Hepatitis B. So, there was no unanimity of decision regarding the blood group association with Hepatitis B. Given the large sample size examined in the current study, it should give a pretty good accurate idea about this association.

\section{CONCLUSIONS}

A particular blood group may have more chances of contracting a particular infection. AB-ve is the blood group that shows maximum sero-positivity of Hepatitis B virus infection in three consecutive years in this particular population of blood donors.

Data sharing statement provided by the authors is available with the full text of this article at jemds.com.

Financial or other competing interests: None.

Disclosure forms provided by the authors are available with the full text of this article at jemds.com.

This study was done jointly by Institute of Blood Transfusion Medicine and Immunohaematology, Kolkata and Department of Anatomy, R.G. Kar Medical College and Hospital, Kolkata. I extend my sincere thanks to the Director and Deputy Director, IBTMI for supporting our work. I also thank the technical staff of IBTMI. This study could not be done without the help of my HOD and faculties of Department of Anatomy, R G K MCH, Kolkata.

\section{REFERENCES}

[1] Tagny CT, Diarra A, Yahaya R, et al. Characteristics of blood donors and donated blood in sub-Saharan Francophone Africa. Transfusion 2009;49(8):1592-9.

[2] Trépo C, Chan HLY, Lok A. Hepatitis B virus infection. Lancet 2014;384(9950):2053-63.

[3] WHO. Global hepatitis report, 2017. http://www.who.int/hepatitis/publications/globalhepatitis-report2017/en/\#

[4] Cooling L. Blood groups in infection and host susceptibility. Clin Microbiol Rev 2015;28(3):801-70.

[5] Lao TT, Sahota DS, Chung MK, et al. Maternal ABO and rhesus blood group phenotypes and hepatitis B surface antigen carriage. J Viral Hepat 2014;21(11):818-23.

[6] Mohammadali F, Pourfathollah A. Association of ABO and $\mathrm{Rh}$ blood groups to blood-borne infections among blood 
donors in Tehran-Iran. Iran J Public Health 2014;43(7):981-9.

[7] Szmuness W, Prince AM, Cherubin CE. Serum hepatitis antigen (SH) carrier state: relation to $\mathrm{ABO}$ blood groups. Br Med J 1971;2(5755):198-9.

[8] Szmuness W, Hirsch RL, Prince AM, et al. Hepatitis B surface antigen in blood donors: further observations. J Infect Dis 1975;131(2):111-8.

[9] Behal R, Jain R, Behal KK, et al. Seroprevalence and risk factors for hepatitis $\mathrm{B}$ virus infection among general population in Northern India. Arq Gastroenterol 2008;45(2):137-40.

[10] Sreedhar Babu KV, Bandi S, Kondareddy S, et al. Association of $\mathrm{ABO}$ and $\mathrm{Rh}$ blood groups to $\mathrm{HBV}, \mathrm{HCV}$ infection among blood donors in a blood bank of tertiary care teaching hospital in Southern India: a retrospective study. Int J Res Med Sci 2015;3(7)1672-76.

[11] Tyagi S, Tyagi A. Possible correlation of transfusion transmitted diseases with Rh type and $\mathrm{ABO}$ blood group system. J Clin Diagn Res 2013;7(9):1930-1.

[12] Omar AAA, Al-Hayan NN, Mohammed MJ. The infection with HBV and HCV and their relationship to ABO blood group among blood donors. J Fac Med Baghdad 2012;54(1):52-5.

[13] Das S, Kumar MLH. Association of blood group types to hepatitis $\mathrm{B}$ and hepatitis $\mathrm{C}$ virus infection among blood donors: a five year Instititional based study. Int J Basic App Med Sci 2012;2:191-5.

[14] Kumar MR, Rao MS, Pulicherla KK, et al. Studies on the distribution of hepatitis B (HBV) and Human Immunodeficiency Virus (HIV) - their relation to blood groups and Rhesus(Rh) factor in Guntur district of Andhra Pradesh, India. Asian J Pharm Clin Res 2013;6(1):109-111.

[15] Satoor AS, Zafer MH. Hepatitis B virus markers in male blood donors. Bahrain Med Bull 2002;24(4):1-6.

[16] Prabhakar K. Incidence of HIV and HBsAg in blood donors a typical indian scenario. Int Conf AIDS 1993;9(1):551.
[17] Kulkarni AG, Aloowooja FO, Wayo GB. Prevalence of Hepatitis B Surface Antigen in Northern Nigerian Blood Donors. Vox Sanguinis 1986;50(3):151-3.

[18] Joshi SK, Ghimire GR. Serological prevalence of antibodies to human immunodeficiency virus (HIV) and hepatitis B virus (HBV) among healthy nepalese males--a retrospective study. Kathmandu Univ Med Journal 2003;1(4):251-5.

[19] Odenigbo C, Oguejiofor C, Okonkwo U, et al. Prevalence of antibodies to hepatitis $\mathrm{C}$ virus in blood donors in Nnewi, South-Eastern Nigeria: in association with blood groups. The Internet Journal of Gastroenterology 2010;10:2.

[20] Anwar MS, Siddiqi GM, Haq S, et al. Association of blood group types to hepatitis $\mathrm{B}$ and hepatitis $\mathrm{C}$ virus infection. Biomedica 2011;27:57-61.

[21] Ghannad MS, Naseri Z, Hosseini SM, et al. Evaluation of accompaniment of $\mathrm{ABO}$ blood groups system and rhesus blood group types with infection to hepatitis B virus and hepatitis C virus in Hamadan, Iran. Int J Med Res Health Sci 2016;5(4):1-5.

[22] Nigam JS, Singh S, Kaur V, et al. The prevalence of transfusion transmitted infections in $\mathrm{ABO}$ blood groups and Rh type system. Hematol Rep 2014;6(4):5602.

[23] Liu J, Zhang S, Liu M, et al. Distribution of ABO/Rh blood groups and their association with hepatitis B virus infection in 3.8 million Chinese adults: a population-based cross-sectional study. J Viral Hepat 2018;25(4):401-11.

[24] Memon FA, Ujjan ID, Memon AI, et al. Seroprevalence of transfusion transmitted infections among different blood group donors at Blood Bank LUMHS, Hyderabad. Pak J Med Sci 2017;33(2):443-6.

[25] Arif SH, Saeed N, Alam K, et al. Association of ABO and Rh blood group with transfusion transmitted infections (TTI) among blood donors in north India. J Blood Disord Transfus 2019;10(4). 